\title{
NATIVE AMERICAN WOMEN: \\ BRINGING GENDER ISSUES INTO LITERATURE
}

Juliana Salles é mestra em literaturas de língua inglesa pela Universidade do Estado do Rio de Janeiro.

E-mail: juliana.salles18@gmail.com

\begin{abstract}
From colonization to the current struggle of Native women authors, this article aims at pointing out the basis of most Native American nations and show how Native women, in the last decades of the $20^{\text {th }}$ century have been using literature to deconstruct the stereotypical image the colonizers have created of them and their people.
\end{abstract}

\begin{abstract}
Resumo: Desde a colonização até a atual luta das mulheres nativas, este artigo tem como objetivo apontar a base da maioria das nações nativo-americanas além de mostrar como mulheres nativas, nas últimas décadas do século $\mathrm{XX}$, têm usado a literatura como uma forma de desconstruir a imagem estereotipada de si e seu povo que o colonizador criou.
\end{abstract}

Even though most traditional History books do not comprise the time before the arrival of the Europeans to the northern part of the American continent, it is important to state that this area was not as "new" as the explorers claimed. In fact, "[t]he designation 'New World' is itself telling, for of course the world of North America was anything but 'new'. Aboriginal peoples had inhabited the area for centuries before the first Europeans appeared off the coast of Newfoundland in search of rich fishing grounds" _ (SUGARS; MOSS, 2009a, p. 16).

At the time when the Spanish intended to build their Empire in the "New World", what is now the territory of Central America served as harbor to Columbus and his soldiers. This first documented contact, back in the fifteenth century, triggered magnificent exchanges of culture and of biological systems. Historians George B. Tindall and David E. Shi, in America (1989) affirmed it was "[...] an exchange of such magnitude and rapidity as humanity had never known before" (TINDALL; SHI, 1989, p. 6), new animals and plants, devices and food, medicine and language became part of the Europeans' lives. However in this great exchange, illnesses were also brought to the "new land": whole communities were devastated by minor diseases such as measles, and also major infections (which spread quickly) as smallpox and typhus contributed to the loss in some tribes of "90-95 percent of their population within the first century of European colonization" (TINDALL; SHI, 1989, p. 8). It was after the news of Columbus' arrival in the "new land" that other professional explorers decided to take a chance at finding a way to get to the Orient. The first to lay eyes upon North America was John Cabot in 1497; this Venetian explorer was sponsored by the English king, but the British were much too worried about internal conflicts, so Cabot's findings did not become a priority just then.

After the Spanish had built their Empire in the "New World", the whole land was Spanish (except for Brazil, under Portuguese rule) and this nation started to exploit the area and its natives. As time went by, England and France started to become serious threats to Spain since both countries were in want of riches and strongly affected by the Protestant Reformation. France posed the first threat by making their initial attempt at colonization: near the current territory of Québec, the explorer Jacques Cartier established a colony in 1542 which did not last long. Only after approximately half a 
century, new settlements were established in Nova Scotia and Québec and effective colonization in what would become the U.S.A. and Canada actually started. In those colonies, the French engaged in trade with the Natives, while Jesuit missionaries worked on their pagan souls. Soon, as the missions continued, the French took their colonies southwards; in the early eighteenth century a settlement called New Orleans was established, and by that time, France controlled great part of the inland waterway in North America, but "it was a deceptive control because the French monarchy never emphasized permanent settlement. Instead, it viewed the region almost solely as a source for trade" (TINDALL; SHI, 1989, p. 14).

From mid-sixteenth century onwards the strength of the Dutch and English started to threaten the Spanish as well, and in 1588, when their Armada was defeated by the English, the latter realized their enemy's navy was no longer considered invincible. The English colonization began in 1584, when an expedition was sent to explore and find out a way to found a settlement colony in America. In 1587, settlers arrived in the land around North Carolina named Roanoke and set up a colony. This settlement, however, did not last long: by 1590 there was absolutely no trace of those people, and according to Tindall and Shi, "There was not a single Englishman in North America when Queen Elizabeth died in 1603" (TINDALL; SHI, 1989, p. 15). Not until 1607 was there an English settlement colony in the American territory.

Despite the clear economical interest in the colonies, the English, as well as the French, started settler colonies, which according to Bill Ashcroft et al (2001) is one of the

[...] two types of European colonies: settler (or settler-invader) colonies and colonies of occupation. Nigeria and India are examples of colonies of occupation, where the indigenous people remained in the majority but were administered by a foreign power. Examples of settler colonies where, over time, the invading Europeans (or their descendants) annihilated, displaced and/or marginalized the indigenes to become a majority non-indigenous population, include Argentina, Australia, Canada and the United States (ASHCROFT, et a., 2001, p. 211).

This definition is extremely relevant when it comes to the analysis of Native American peoples, since it would be confusing to call this country "colony", as this process of colonization differs from the ones that took place in the Caribbean and Africa in the end of the nineteenth and on the twentieth century. Furthermore, when it comes to the settlers in the areas of the USA, it can be said that they have an ambiguous position because as they have been dislocated from their original land and had to adapt to this new place, they tend to appropriate some of the "nativeness" to their own selves, which represents a kind of "re-birth" in the new land (see ASHCROFT et al, 2001, p. 211). The settlers are both discriminated by the colonizers and the colonized since they do not properly fit either positions, and, at the same time, can also be considered both colonizer and colonized - the former, because they share the too many characteristics with the colonizers, and the latter because they have come to settle and assimilated part of the 
Native culture (ASHCROFT et al, 2001, p. 211 - 212). In fact, there was great exchange of cultures at this encounter, as it was detailed by Cynthia Sugars and Laura Moss:

For the Europeans, this included exposure to new traditions, new foods, new wildlife, and new landscapes, all of which in a very short time ceased to be 'new' and became regarded as familiar and natural. (...) Likewise, Aboriginal communities were altered by their interactions with Europeans, not only by acquiring new technologies or being converted to Christianity, but also by using the fur trade as a way of involving Europeans in their own trading alliances and rivalries with other Aboriginal groups (SUGARS; MOSS, 2009a, p. 27).

Trade was one of the activities that involved exchange between Natives and Europeans. Both France and England had been rivals for a long period of time, and the fur trade became an aggravating factor in this rivalry. Not until the seventeenth century, though, did it reach the North American lands - putting to an end the years that area had been neglected by them (SUGARS; MOSS, 2009a, p. 18). Nevertheless, it is important to state that not only did the Natives help Europeans in the exploration of the land, but also in fur trade - without the Aboriginal groups there wouldn't have been any settlement either (SUGARS; MOSS, 2009a, p. 16).

In the encounter of explorers/settlers and Aborigines in North America, as much as there was cultural exchange, there was also the Europeans' cultural imposition on Natives. Even though, at the moment of contact, natives found themselves in great disadvantage - for the Europeans had such great weaponry and were so well-equipped those that did not succumb to diseases still resisted for centuries. According to Tindall and Shi:

They displayed an amazing capacity for adapting to changing circumstances, incorporating European technology and weaponry, forging new alliances, changing their own community structures, and in a surprising number of instances converting whites to their simpler way of life (TINDALL; SHI, 1989, p. 3).

Still, the Aborigines were seen as different and exotic even though they were Native in America - and being different meant being inferior, in need of help so they could evolve.

This inferiority associated with the Natives in North America (and Natives in many other colonized lands as well) seems to have its origins in narratives of exploration in the "Newfoundland", as explorers had been sent by the king or by companies, there was the need of documents to describe these places. According to Sugars and Moss:

Exploration and travel narratives were extremely popular in Europe from the sixteenth century onward. While many of these written accounts began as journals or reports composed for the directors of a fur-trading company or for the royal sponsor in England 
or France, in many cases the writers revised their accounts for commercial publication. The popularity of these narratives drew on a passion for exotic depiction of what was for Europeans a "new" and unfamiliar world. Many of these travel narratives included elaborate maps and illustrations, as well as detailed descriptions of North American Aboriginal peoples, who appeared as exotic to Europeans as did the peoples of China and India (SUGARS; MOSS, 2009a, p. 19).

By publishing the colonizer's point of view exclusively, it was clear that those who were indeed the "others" in the Newfoundland were the ones who had the power to document the world to a number of people and determine "[...] the ways readers would imagine and assess the places and peoples they described" (SUGARS; MOSS, 2009a, p. 22). Natives then, were depicted as the "others", and according to Ashcroft et al (2001):

In general terms, the 'other' is anyone who is separate from one's self. The existence of others is crucial in defining what is 'normal' and in locating one's own place in the world. The colonized subject is characterized as 'other' through discourses such as primitivism and cannibalism, as a means of establishing the binary separation of the colonizer and colonized and asserting the naturalness and primacy of the colonizing culture and world view (ASHCROFT et al, 2001, p. 169).

It can be said then, that history and literature was one of the main means that framed natives as primitive, and therefore savage and uncivilized.

After the arrival of Columbus to America, several works of art depicted his encounter. Stuart Hall, in his article "Thinking the Diaspora: Home-Thoughts from Abroad" (1999), mentions the famous engraving of Europe encountering America, in which "Amerigo Vespucci is the commanding male figure, surrounded by the insignia of power, science, knowledge and religion: and 'America' is, as often, allegorized as a woman, naked, in a hammock, surrounded by the emblems of an - as yet unviolated exotic landscape" (HALL, 1999, p. 5). Considering this comparison in a broader sphere, the American continent and therefore the natives were gendered as female, which brought several consequences:

Further, by gendering the continent as female, these maps highlight the notion that the land is a 'virginal' space, ready to be tamed, controlled, and overtaken. The feminization of the new space makes it easier to justify conquest in a patriarchal system such as the European one of the time. The female body of America becomes the object of male desire in commercial gaze, and thus becomes an obvious metaphor for desired colonial domination (SUGARS; MOSS, 2009a, p. 29-30).

Such notions led the Europeans to believe that this land and its inhabitants needed to evolve, since their way of living was uncivilized and basically wrong. For that to happen there had to be the imposition of the colonizers' culture, which included patriarchalism and which would dismantle the pillars of Native societies.

Despite being mentioned in European records and contributing to the exploration of their own lands, natives had no chance to give their own version of what actually 
happened, not even of what had already happened by the time these records were written down. As claimed by Sugars and Moss, for centuries, the Aboriginal peoples, so affected by European imperialism did not have a chance to be heard, and that is why, in the last decades of the twentieth century, many Aboriginal authors have provided the world with alternative perspectives on the colonizers' accounts (SUGARS; MOSS, 2009a, p. 30-31) and, ironically enough, using literature to deconstruct the stereotypical images of them created by Europeans ${ }^{1}$.

\section{1) The Natives from North America}

According to Tindall and Shi, in America (1989), the North American tribes prior European settlement, were smaller, less settled and scattered when compared to other American tribes; migration was common in order to find food and better places to live in, and on the permanent settlements built by them, land was owned communally, but individuals were allowed to own what they produced (TINDALL; SHI, 1989, p. 2). Even though nowadays there are over hundreds of tribes across North America, back in the time of colonization the ancestors of "the Pueblos, Creeks and Iroquois [n] ever approached the level of social organization or cultural sophistication achieved by the Mayas or Aztecs" (TINDALL; SHI, 1989, p. 2). They had, however, their own organizational systems.

With the arrival of Europeans to the "Newfoundland", several colonizing practices were being applied and they represented a "[...] virtuous and necessary 'civilizing' task involving education and paternalistic nurture" (ASHCROFT et al, 2001, p. 47). Initially, the colonizers had to make sure the Natives were depicted as inferior not only when it came to trade or lifestyle, but also in a natural state, and this practice is a construct that has endured for centuries also among natives.

Many traditional Aboriginal people lived in gynocratic societies, and according to Paula Gunn Allen:

Some distinguishing features of a woman-centered social system include free and easy sexuality and wide latitude in personal style. This latitude means that a diversity of people, including gay males and lesbians, are not denied and are in fact likely to be accorded honor. Also likely to be prominent in such systems are nurturing, pacifist, and passive males (as defined by western minds) and self-defining, assertive, decisive women. In many tribes, the nurturing male constitutes the ideal adult model for boys while the decisive, self-directing female is the ideal model to which girls aspire (ALLEN, 1992, p. 2).

\footnotetext{
${ }^{1}$ In The Norton Anthology of North-American Literature (2012), there is reference to some authors that have gone largely unnoticed, such as Zitkala Sa (Gertrude Bonnim), in the $19^{\text {th }}$ century. 
Stephanie Sellers (2008) states that "[...] the governing, ceremonial, and social structures of most gynocratic Native nations are based on gendered halves: women's duties and men's duties. The purpose of that is to maintain harmonious balance with[in] the nation [...]" (SELLERS, 2008, p. 7). However, even though balance was highly valued

[...] this does not necessarily mean women and men had equal autonomy over their lives and similar opportunities for power. Even in some Native nations that were structured by a gender complementary system, women suffered from the effects of unequal power and experienced types of hardship present in patriarchal systems. However, in most gynocratic nations and certainly in the Eastern Woodlands [U.S.A.], women lived free of the constraints typically found in patriarchal systems (SELLERS, 2008, p. 7).

Kathleen Donovan gives some examples of activities destined to men and to women: men would be involved in "[...] more solitary pursuits of fishing, hunting, and trapping while women's activities included communal fishing and trapping of small game near camp, and the harvesting of berries, nuts and wild rice. Men were in charge of hunting large animals [...]" (DONOVAN, 1990, p. 22). Women were also responsible for controlling food and, at the same time, for maintaining the sense of community and interdependence among other members (DONOVAN, 1990, p. 22). In fact, one of the bases of these nations' traditions were women as key elements in their creation stories: their bodily functions, their psycho-spiritual experiences, women as healers, as political leaders and as the source of all manner in life were ever-present traits in these stories (SELLERS, 2008, p. 3-4). Sellers also declares there were animals, males and transgenders along with women (SELLERS, 2008, p. 6). It is crucial to state though, that each nation had its own story which framed that people's philosophy.

It is of utmost importance for the understanding of Native culture that these nations' pre-colonial traditions considered all beings sacred, because of their relationship with the earth. This connection with the land is one of the main features that differentiate the Natives' from the Western culture. The way

[...] the earth is named, conceptualized, and the multitude of different ceremonies conducted to communicate with or revere her ${ }^{2}$ vary widely among Native nations; nevertheless, all Native nations do indeed revere her and see her, literally and metaphorically, as the source of all life (SELLERS, 2008, p. 11).

The beginning of the colonization process brought about the undermining of Natives' societal structure. And since colonization involves subjugation, the Whites forced their values over the colonized because the former thoroughly believed the Natives' culture of worshiping the land, and mainly having women play important roles in society were terribly wrong. Not only did Natives have their values questioned, but

\footnotetext{
${ }^{2}$ The earth is referred to as "she" in Native traditional cultures. 
those were soon taken over by the patriarchal system: the women, who were formerly essential to society and households, were now basically "second-class citizens". Concerning the Whites' patriarchalism, Sellers claims it

[...] is not simply the centralization of men but the simultaneous subjugation of women in order for the men to maintain that privilege for themselves and all subsequent male generations. Patriarchy features an exclusive class system where only a small percentage of males at the top of the system have wealth; however, all males benefit from the patriarchal system because of the inherent privilege of men, even if they are poor (SELLERS, 2008, p. 84).

Gynocracies, then, were one of the settlers' greatest fears, since European men could not conceive the fact that their women would be as powerful as the native ones, and neither could they let the indigenous culture survive and therefore undermine the whole colonization process (SELLERS, 2008, p. 91). Historian and writer Devon Abbot Mihesuah posits in the introduction to her book Indigenous American Women: Decolonization, Empowerment, Activism (2003) that:

Native women did have various degrees of power, equality, and prestige within traditional tribal structures; the philosophies and policies of colonialism changed that status for many women; and Indigenous women still feel the effects of colonialism. The past does impact the present (MIHESUAH, 2003, p. xv).

Actually, in the beginning of colonization, Christian missionaries started the conversions among the Natives by focusing on men, believing that by converting men, women would simply follow their fathers, brothers and husbands, since, to them, those were the head of households (DONOVAN, 1990, p. 22). Then, realizing how differently Native communities worked, missionaries started to force them into assimilating the European values which consequently led to the internalization of racism, since they started to "reject their own culture that centralized women because they were told it was wrong, even 'savage' and 'ungodly' to believe in it anymore" (SELLERS, 2008, p. 8). Christian missionaries did not suspect that eventually those women would gain strength and become the authors of their own lives, and contribute to filling in the gap left in official history. About that, mixed-race literary critic, poet, activist and novelist Paula Gunn Allen claimed in the preface to The Sacred Hoop:

It seems that gynocracy is a well-advanced social system among all the tribes, and while it falls ever more into disrepute and ignominy as progressive modernism makes its ugly inroads into native life, it simultaneously takes on new life, appearing in new guise and revealing its uncommon tenacity. [...] The appearance of this decade's wealth of literature, art, and scholarship by Native American women is another welcome sign of our coming spring (ALLEN, 1992, p. xiii).

\section{2) Native literature}


As stated by Allen, there is such thing as American Indian Literature and it can be divided into two categories: traditional literature and genre literature of the present. Allen goes one stating that:

Traditional literature can be further divided into ceremonial and popular varieties - that is, into canonical works and those that derive from the canon but are widely told and appeal to audiences gathered on social occasions. Contemporary works, or genre literature, can be divided into the classic western categories of poetry, short fiction, the novel, and drama, with addition of autobiography, as-told-to narrative, and mixed genre works. Structural and thematic elements from the oral tradition, usually from the writer's own tribe, always show up in contemporary works by American Indians, and elements from contemporary, non-Indian works sometimes show up in contemporaneous tribal social literature (ALLEN, 1992, p. 4).

Before the arrival of European colonizers, the natives had not yet had contact with the process of writing or with written words as we know them - as those were created and developed in the West - so, orality was used to pass on knowledge among Natives. As they did not keep written records, the main sources of knowledge were (and still are) the elders, whose main role was to tell stories and teach other members of the community; as traditional nations were matrilineal, grandmothers were usually the beholders of such powerful position. For being wiser, many Native authors make reference to grandmothers as the most respectable person in the family/community, the one who teaches lessons for life, usually by means of stories - Maria Campbell's autobiography, Halfbreed (1973), brings Cheechum; Leslie Marmon Silko's The Turquoise Ledge (2010) brings Grandma A'mooh and Grandma Whip; the epilogue to Bobbi Lee Indian Rebel (1990) brings Lee Maracle's reference to Ta'ah (greatgrandmother); Paula Gunn Allen's The Sacred Hoop (1992) also brings the figure of a great-grandmother.

As stated by Ashcroft et al (2001), it was in the hands of missionaries that the written forms and the acquisition of literacy became great symbols of civilization and, therefore, salvation. Until recently, anthropologists, media theorists, mission societies, and government policy makers still believed "[...] that oral and literate cultures are successive, mutually exclusive stages in a single, unavoidable path of cultural evolution" (TOORN, 2004, p. 24). This, Toorn goes on, justified forced-assimilation processes as the oral cultures would be evolving with the acquisition of literacy. According to Martinican writer, poet, essayist and critic Edouard Glissant, in his Caribbean Discourse: Selected Essays (1989), Literacy is intricately connected to an "all-powerfulness", helping to justify domination and rule citizens from oral civilizations (GLISSANT, 1989, p. 76). From the last decades of the twentieth century onwards though, despite the fact that "Aboriginal cultures are now passed down through a variety of additional means such as books, magazines, dramatic and musical performances, films, television, radio and the Internet" (TOORN, 2004, p. 24), Native 
writers have realized the importance of the oral culture and made of it a source for their writing.

Actually, Toorn states the term used to refer to the oral discourse of Native peoples - which includes songs, stories, and ritual utterances in general - is "Orature", as it is a contradiction to use the term "oral literature" (TOORN, 2004, p. 24). In The Norton Anthology of North-American Literature (2012), there is reference to the controversial aspect of this term. As the term literature comes from Latin, litteratura, it brings in "littera", the written word, the letter implied, making the combination of "oral" and "literature" a controversy. The choice to refer to Native expressions of oral tradition as "orature" is also suggested in the anthology. So, since the 1970s, Natives started being noticed as authors of serious literary works, and by means of written words have been showing the relevance of orature, as well as of the stories they tell natives and non-natives (BAYM, et al., 2012, p. 7).

Concerning the problems the Aboriginal peoples have been facing throughout history, Native-American writer and theorist Paula Gunn Allen has written about the Native American Renaissance, a concept which can be applied to the whole NorthAmerican continent. This renaissance, besides solving severe political and economic issues concerning Natives, also

[...] encompasses the widespread return of Indian people from every tribe to traditional practices and celebrations, the continuing and increasing publication of literary works by American Indian Arts - both contemporary and traditional - in Indian-owned and operated museums and galleries as well as in wealthier venues recognized by peoples around the world, These occurrences, along with a growing number of films, plays, dance performances, and scholarship devoted to themes of American Indian life and thought, constitute a mighty cultural flowering, a truly Native American Renaissance (ALLEN, 1992, p. x).

Allen's concept is intricately connected to the process of colonization the U.S.A. went through, and according to Glissant, this area, like the French Caribbean, had many ruptures in its history and could not have a historical consciousness gradually formed ${ }^{3}$. The Natives from North America went through this process and lack a history of their own because of the "[...] dislocation of the continuum, and the inability of the collective consciousness to absorb it all [...]" (GLISSANT, 1989, p. 62) - the consequence of which Glissant calls nonhistory.

In order to regain this historical space, the French Caribbean needed to break free from the colonial ideology imposed on them, since the erasure of their traditional values brought with colonization kept them from resisting (GLISSANT, 1989, p. 63). Likewise, the Natives have been through a process of erasure of their traditional values, which seriously affected their strength to resist openly and continuously.

\footnotetext{
${ }^{3}$ Glissant is writing specifically about the French Caribbean, but what he says applies to other colonized areas as well. 
As mentioned previously, the Natives, just as the French Caribbean, did not have the chance to tell their side of History, and were depicted as the Europeans wished. To Glissant:

\begin{abstract}
"History [with a capital $\mathrm{H}$ ] ends where the histories of those peoples once reputed to be without history come together." History is a highly functional fantasy of the West, originating at precisely the time when it alone "made" the history of the World. If Hegel relegated African peoples to the ahistorical, Amerindian people to the prehistorical, in order to reserve History for European peoples exclusively, it appears that it is not because these African and American peoples "have entered history" that we can conclude today that such a hierarchical conception of the 'march of History' is no longer relevant (GLISSANT, 1989, p. 64).
\end{abstract}

This hierarchy still exists, but with the publishing of several literary works by Natives from North-America, it has been possible to show some of the other sides of History. But how to write one's version of History when the natives are marked by a nonhistory?

Glissant declares that as throughout the colonization process the collective memory was also erased, the Native authors must "dig deep" into their memories, getting the signs from what she/he had got from everyday life (GLISSANT, 1989, p. 64). That way, the author would connect culture and nature - what a person remembers from natural events - and be able to "fill in the gaps" left by official History with memories and stories. This process, then, has a strong fictional characteristic once memory is a personal asset often affected by several factors and is, thus, rarely the same for two individuals.

This "digging" might have been difficult once many elders have passed away and carried along with them precious elements of Native culture. The publishing of Native authors back in the 1970s started being done by small publishers - sometimes even publishers specialized on natives' works, or women's - and usually under the approval of white editors who sometimes shaped the narratives so it could fit the market, which showed how much further natives still needed to go to actually be heard. Such difficulty faced by Native authors has a lot to do with what Glissant stated on the similarities between History and Literature: "[...] in History as in Literature [,] Western thought (since it is the one that prevails here) [,] has practiced this form of domination and [...] it has not managed (in spite of persistent advantages) to resist the liberating force of diversity" (GLISSANT, 1989, p. 71). It is then in attempts to fight this double hegemony over History and Literature that minorities have been struggling with to be heard, while dealing with poverty and oppression (p. 76). Glissant argues that it is on Natives' claim for their voice that we realize the fragmented aspect of literature and how "[i]n it lie histories and the voice of peoples. We must reflect on a new relationship between history and literature. We need to live it differently" (GLISSANT, 1989, p. 77). This struggle involves self-affirmation about "sovereignty and 'first nationhood'[,] [...] continuity of habitation, aboriginality and often a 'natural' connection to the land" (CLIFFORD, 1997, p. 308). 
Theorist James Clifford claims that the predicaments of tribes are, concerning certain historical circumstances, diasporic. On the other hand, even though diaspora necessarily invokes dislocation (not necessarily involving the idea of return), the NorthAmerican tribes have been through great loss and displacement: at the moment the settlers arrived, the Natives had their lands invaded and would eventually be enclosed in the so-called reservations. Clifford further explains that:

[...] inasmuch as diasporas are dispersed networks of people who share common historical experiences of dispossession, displacement, adaptation, and so forth, the kinds of transnational alliances currently being forged by Fourth World ${ }^{4}$ peoples contain diasporic elements. United by similar claims to "firstness" on the land and by common histories of decimation and marginality, these alliances often deploy diasporist visions of return to an original place - a land commonly articulated in visions of nature, divinity, mother earth, and the ancestors (CLIFFORD, 1997, p. 309).

These ideas of "return" are still strong - the will to reconnect with traditions and communal bonds is a feature that is very much part of many Natives' lives.

\section{3) Native women writers}

Commenting on the loss of power suffered by Native women over the centuries, Paula Gunn Allen has pointed out that:

The status of tribal women has seriously declined over the centuries of white dominance, as they have been all but voiceless in tribal decision-making bodies since reconstitution of the tribes through colonial fiat [...]. But over the last thirty years women's sense of ourselves as a group with a stake in the distribution of power on the reservations, in jobs, and within the intertribal urban Indian communities has grown (ALLEN, 1992, p. 30).

Power is a central issue when it comes to Native women nowadays. And in order to regain the power those women once had, modern tribal women have been trying to redefine themselves, as much as non-native women have been doing from the 1960s on (ALLEN, 1992, p. 43). Concerning this struggle, Allen reiterates how multifaceted Native women's identity really is:

\footnotetext{
${ }^{4}$ The term "Fourth World" was first used in a reference by Mbuto Milando, first secretary of the Tanzanian High Commission in a conversation with George Manuel, Chief of the National Indian Brotherhood of Canada, referring to the natives who would be immersed on their own traditional culture these would then, be part of the Fourth World. In 1974, with the publication of The Fourth World: An Indian Reality, the term gained the idea of marginalized and poor nations/peoples. Moreover, it is destined to define the group of people which does not have a nation-state. (From: < http://en.wikipedia.org/wiki/Fourth_World> Last accessed on March $13^{\text {st }}$ 2015.) 
[...] though she is at times beset by her knowledge of the enormous gap between the life she lives and the life she was raised to live, and while she adapts her mind and being to the circumstances of her present life, she does so in tribal ways, mending the tears in the web of being from which she takes her existence as she goes (ALLEN, 1992, p. 45-46).

However significant being a woman can be, saying gender is the defining factor in a woman's life would be an absolute oversimplification, especially when it comes to Native ones. Even further essentializing would be to state that being a White woman is the same as a being a Métis or a Laguna Pueblo woman, or claiming that a poor Native woman is the same as a wealthy Native woman. Paula Gunn Allen claims a native woman's "sense of herself as a woman is first and foremost prescribed by her tribe" (ALLEN, 1992, p. 43).

In the chapter "Making History: Reflections on Feminism, Narrative and Desire" (1998), Susan Stanford Friedman affirms that many other factors affect the gender system and that "[d]iscourses of multiple oppression, intersection, positionality, standpoint, and contradictory subject positions have to a large extent supplanted the monolithic category of 'woman' in academic feminism in the United States" (FRIEDMAN, 1998, p. 208). These multiple discourses may be associated with what Elleke Bohemer refers to as diversity or "layeredness" of women's experience, that is, in each woman there are several layers and features that influence her. Likewise, there are varied "forms of self expression and community other than those prevalent in the West" (BOHEMER, 2005, p. 218). Some of those influences may then be foregrounded depending on the situation: if a woman in a professional environment, for instance, needs to be defined among a group of men, despite the myriad of influences that make her who she is, gender will, in that case, speak louder. In another situation, depending on the group she is inserted in, or the purpose of such gathering or of such distinction, this woman might have to have other features underscored; this is the theory of relationality.

Since their subjectivity is framed by several influences, women, as well as their autobiographical writings, are framed by relationality and often opposed to men's, mostly connected to individuality. According to Hertha D. Sweet Wong (1998) - a Berkeley University Professor who does research on autobiography, Native American literatures and visual studies -, this dialogic opposition can be paralleled to the oppositional Native American (other, different) and European (individual, universal) subjectivities, for male subjects are claimed to be connected to individuality, universal subjectivity, while women would be framed on relations, and therefore different. Wong overtly states that this analogy is merely reductive oppositionality, but it is important to highlight its relevance to her unfolding of ideas; her major point though, seems to be grounded on the cultural aspect: what would be the differences then between Native American men and women? If women's subjectivity is directly proportional to the Native one, and therefore to difference, where do Native American ${ }^{5}$ women stand? 
Where do Native American men stand? However intricate this issue may be, the point lies on the fact that relationality thoroughly affects Native individuals nowadays for their multiple cultural influences in the globalized world as well as other aspects that might be highlighted or not, such as skin color, sexual orientation, and nationality ${ }^{6}$. Furthermore, indigenous subjectivities specifically offer a range of choices, referred by Wong as "nonoppositional relationality" (WONG, 1998, p. 170). This means that the Natives do not have to choose between being Native or being a woman, for instance. For them, there are alternative choices, and one facet of their subjectivities does not exclude others.

\section{4) Native American women authors in Native American literature}

Paula Gunn Allen states that "[1]iterature is one facet of a culture" (ALLEN, 1992, p. 54), and it is not hard for someone to see the relevance and level of complexity, or symbolic significance of her/his culture's literature (ALLEN, 1992, p. 54), but it is sometimes hard to appreciate another culture's literature. The belief that all creatures share the creation process, making all things sacred (ALLEN, 1992, p. 57) very much influences the structure of Native American literature - that "[...] is determined by its relation to creative empowerment, its reflection of tribal understandings, and its relation to the unitary nature of reality" (ALLEN, 1992, p. 59) - making it hard for non-Indian readers to fully understand it.

Native American literature has often been misread, being called "primitive", "pagan", "childlike", "savage" by naïve readers (ALLEN, 1992, p. 54). When it comes to the Western literary canon, there are texts that publishers, reviewers, teachers, "educated people", and government agencies have presumed to be the best, or to count most (KRUPAT, 1994, p. 8-9), while there are no such texts to refer to the Native American canon. However, some authors have been considered the most important ones, such as Momaday, Silko and Erdrich, for instance, who have been highly regarded due to their novels (KRUPAT, 1994, p. 9). It was after Momaday's Pulitzer, that many non-Indians started to show appreciation for his work, and therefore turned him into a renowned Native American writer.

According to Arnold Krupat, in the first moment, Native literature was a response to white invaders (KRUPAT, 1994, p. 10), and soon became a way to show whites that the Natives could write about themselves, highlighting cultural differences, subverting genres, and teaching non-Indians some of the values that were important to them. As Paula Gunn Allen stated, the purpose of traditional American Indian literature is never self-expression. The tribes seek the depiction of a private self in harmony with her/his reality "[...] to verbalize the sense of the majesty and reverent mystery of all things, and to actualize, in language, those truths that give to humanity its greatest significance and dignity" (ALLEN, 1992, p. 55).

\footnotetext{
${ }^{6}$ By nationality it is meant the nation from which one is derived from, such as the Cherokee, or the Inuit. 
As women are central to most Native American communities, there is no subversion (from Native perspective) when women are authorized to sign literary works. Actually, the fact that they wrote literary works was actually subversive, since in traditional culture, there was no such thing as literary works. However, to Western culture, framed upon patriarchalism, having women not only as artists, but as authors which according to theorist Mary Eagleton, implies "authorising" and "authority" (EAGLETON, 2005, p. 2) - meant twice as much if we take into account that Native women are minorities, or ex-centric (HUTCHEON, 1988, p. 62-63) and, for being Native and women, doubly-oppressed. Moreover, for being multiply influenced, Native women's writing tend to deal with several influences instead of containing only features from Native cultures.

\section{References:}

ALLEN, Paula Gunn. The Sacred Hoop: Recovering the Feminine in American Indian Traditions. Boston: Beacon Press, 1992.

ASHCROFT, Bill, et al, eds. Post-Colonial Studies: The Key-Concepts. London: Routledge, 2001.

BAYM, Nina, et al, eds. The Norton Anthology of American Literature. New York: W. W. Norton \& Company, 2012. v. A.

BOHEMER, Elleke. Colonial and Postcolonial Literature: Migrant Metaphors. New York: Oxford University Press, 2005, p. 214-259.

CAMPBELL, Maria. Halfbreed. Lincoln: University of Nebraska Press, 1982.

CLIFFORD, James. "Diasporas". In: Routes: Travel and Translation in the Late 20th Century. Cambridge: Mass \& London, England: Harvard University Press, 1997. p. 302-321.

DONOVAN, Kathleen N. "Metis Women Writers: The Politics of Language and Identity". In: _. Feminist Readings of Native American Literature: Coming to Voice. Tucson: The University of Arizona Press, 1998. p. 15-41.

EAGLETON, Mary. Figuring the Woman Author in Contemporary Fiction. New York: Palgrave Macmillan, 2005. p. 1-57.

FRIEDMAN, Susan. "Making History: Reflections on Feminism, Narrative, and Desire". In: . Mappings: Feminism and the Cultural Geographies of Encounter.

New Jersey: Princeton University Press, 1998, p. 199-227.

GLISSANT, Edouard. Caribbean Discourse: Selected Essays. Charlottesville: University Press of Virginia, 1989, p. 60-77. 
HALL, Stuart. "Thinking the Diaspora: Home-Thoughts from Abroad". In: Small Axe. Vol. 6. September 1999. p. 1-18.

HUTCHEON, Linda. A Poetics of Postmodernism. New York and London: Routledge, 1988.

KRUPAT, Arnold (ed.). "Introduction". In: Native American Autobiography: An Anthology. Wisconsin: The University of Wisconsin Press, 1994. p. 1-15.

MARACLE, Lee. Bobbi Lee Indian Rebel. Toronto: Women's Press, 1990.

MIHESUAH, Devon Abbott. Indigenous American Women: Decolonization, Empowerment, Activism. Lincoln: University of Nebraska Press, 2003.

SELLERS, Stephanie. Native American Women's Studies: A Primer. New York: Peter Lang, 2008.

SILKO, Leslie Marmon. The Turquoise Ledge. New York, Penguin Books, 2011.

SUGARS, Cynthia; MOSS, Laura, eds. Canadian Literature in English: Texts and Contexts. Toronto: Pearson Longman, 2009a (v.1)

TINDALL, George B.; SHI, David E..America. New York: Norton, 1989.

TOORN, Penny Van. “Aboriginal Writing”. In: KRÖLLER, Eva-Marie (ed). The Cambridge Companion to Canadian Literature. Cambridge: Cambridge University Press, 2004. p. 22-48.

WONG, Hertha D. Sweet. "First-Person Plural: Subjectivity and Community in Native American Women's Autobiography". In: SMITH, Sidonie; WATSON, Julia (eds.). Women, Autobiography, Theory: A Reader. Wisconsin: The University of Wisconsin Press, 1998, p. 168-178. 